\title{
Student Satisfaction with E-learning Using Blackboard LMS during the Covid-19 Circumstances: Realities, Expectations, and Future Prospects
}

\author{
Bakr Bagash Mansour Ahmed Al-Sofi \\ Department of English, College of Sciences \& Arts, PO Box \# 101, Al-Namas, 61977, University of Bisha, Kingdom of Saudi Arabia
}

\begin{abstract}
The quick spread of the Covid-19 pandemic has made e-learning mandatory and a strategic choice to ensure the continuity of the learning process. In this changing paradigm, this case study has been undertaken with three main objectives: to explore Saudi EFL learners' satisfaction with the E-learning process compared to students in other departments at the University of Bisha, using Blackboard Learning Management System (LMS); to investigate the critical determinants affecting the e-learners' satisfaction; to identify the university facilities and services incorporated to increase student satisfaction. The Student Satisfaction Index (SSI) model is adapted and contextualized to meet the objectives of the study. A quantitative research design is used in which a questionnaire elicited the data from 538 randomly selected respondents. Content analysis is also used to analyze the infographic reports about the university facilities and services brought in to ensure a successful learning process. The results show that EFL learners are less satisfied with the e-learning process than students enrolled in other departments during the Covid-19 pandemic. The course instructors' facilities and services, technical support, and course content design adversely affect the respondents' satisfaction since these are the best predictors of student satisfaction. The university, however, is seen to have taken significant steps to ensure a successful e-learning process. The study recommends that the course instructors and policymakers collaborate to increase the e-learners' satisfaction taking into account the factors mentioned herein.
\end{abstract}

Keywords: Blackboard LMS, COVID-19 pandemic, E-learning, Student satisfaction index model, Saudi EFL learners.

\section{INTRODUCTION}

In the pre-pandemic period, learners were used to traditional on-campus learning, with some exceptions in using blended courses. With the spread of the Covid-19 pandemic, academic institutions suddenly found themselves in an urgent need to think of innovative alternatives to ensure continuity of the teaching-learning process. They made considerable efforts to utilize the e-learning platforms that ensured a complete shift to online learning in place of on-campus education. Taylor (2007) stated that e-learning helps universities become more digitized and contribute to a digital and knowledgeable society where learning and knowledge sharing can be conducted simply and quickly anytime and anywhere with the help of internet-enabled technologies.

The sudden spread of the Covid-19 pandemic has compelled academic institutions to take immediate actions and think seriously about innovative alternatives that ensure the continuity of the learning process. Such a prompt and unplanned shift to e-learning need more focus and a deeper evaluation of the e-learners' satisfaction with the learning process (Choudhury \& Pattnaik, 2020), the critical factors affecting their satisfaction, and tackling these potential factors. Students and teachers were also unprepared technically and psychologically for fully online learning. Moreover, e-learners' satisfaction and motivation for the e-learning process can affect the achievement of the learning outcomes (Sandybayev, 2020). Therefore, exploring e-learners' satisfaction and tackling the potential obstacles contribute to the improvement of the e-learning process in the future.

Levy (2003) indicated that student satisfaction is crucial to measure e-learning effectiveness. The Student Satisfaction Index (SSI) model, a reliable method to measure student satisfaction in higher education, was adapted to investigate student satisfaction with the e-learning process and the factors affecting their satisfaction. Specifically, this study aims to explore Saudi EFL learners' satisfaction with the e-learning process compared to students enrolled in other departments using Blackboard LMS. It also examines the predictive determinants affecting student satisfaction with the e-learning process. It explores the

Corresponding Author e-mail: bakr4all@gmail.com;

bbmansour@ub.edu.sa

https://orcid.org/0000-0001-6115-313X

How to cite this article: Al-Sofi BBMA, (2021). Student Satisfaction with E-learning Using Blackboard LMS during the Covid-19 Circumstances: Realities, Expectations, and Future Prospects. Pegem Journal of Education and Instruction, Vol. 11, No. 4, 2021, 265-281

Source of support: Nil

Conflict of interest: None.

DOI: $10.47750 /$ pegegog.11.04.26

Received: 11.06.2021

Accepted: 24.08.2021

Publication: 01.10 .2021 
statistically significant differences in e-learners' satisfaction based on variables of gender, academic campus, specialization, education level, residence place, and the tool(s) used to log in the e-learning process. The switch to the process of e-learning requires concerted efforts in terms of excellent preparation of course material and curriculum and suitable technical infrastructure. Therefore, this study also sheds light on existing and new university facilities and services to ensure student satisfaction and success of the learning process during the exceptional situation of the COVID-19 crisis.

This study addresses the following questions:

- RQ 1: To what extent are EFL learners satisfied with the e-learning process during the Covid-19 pandemic compared to students in other departments?

- RQ 2: Are there statistically significant differences between gender, academic campus, specialization, education level, residence place, and the tool(s) used to log in the e-learning process and student satisfaction with the e-learning process?

- RQ 3: Which is the best predictor of student satisfaction with the e-learning process?

- RQ4: What are the university facilities and services preexisting or incorporated to enhance student satisfaction with the e-learning process during the spread Covid-19 pandemic?

\section{Review of Literature}

\section{E-Learning: An Overview}

Al-Ajlan (2016) defined e-learning as an interactive system in which the learning content is available online and provides automatic feedback to students' learning activities. Afifi and Alamri (2014) stated that one of the primary functions of e-learning is to offer a flexible education platform predicated on building knowledge for learners and organizations. Similarly, Lee, L. (2016) anticipated that "online courses are becoming a more widely popular and viable option for many adult learners" (p. 81). Because of the sudden emergence of the COVID-19 pandemic and the lockdown of educational institutions, e-learning has emerged as an innovative teachinglearning way that has ensured a continuous learning process even in these testing times. 'E-learning' term is commonly used interchangeably with 'online learning, 'virtual learning', and 'distance learning.'

The e-learning platforms have many unique characteristics. Means et al. (2010) emphasized that e-learning allows the sharing of ideas, enables learner-centered teaching approaches, allows for instructor accessibility, adds pedagogical benefits, facilitates $24 / 7$ accessibility to learning/course materials, and helps instructors. Similarly, Naveed et al. (2017) stated that "e-Learning teaching-learning methodology provides more flexibility and allows freedom from time, place, physical presence, hectic and stressful teaching-learning, etc., thus playing a vital role in the education system" (p. 94). Thus, e-learning provides learners with greater flexibility in time and place, ensures their safety from the virus, and allows them to be autonomous. They can perform various functions of attending classes, accessing the course contents, doing assignments and activities, and sitting for exams through the available educational platforms while they are at home. It also enhances interactivity between the teachers, students, and the content. On the other hand, instructors can prepare and share course content and educational materials, conduct virtual classes, get feedback, facilitate mutual interaction, and grade assignments and exams from home.

\section{E-Learning at Saudi Universities}

Al-Shehri (2010) stated that different Arab universities have implemented e-learning and achieved considerable levels of success. Al Gamdi and Samarji (2016) demonstrated that in the last decade of the $20^{\text {th }}$ century, universities have been influenced by the digital age and beefing up for greater inclusion of e-learning.

In the Saudi context, the adoption of e-learning in educational institutions has become essential to meet the expectations and needs of students and teachers (Alahmari \& Amirault, 2017; Al-Asmari \& Khan, 2014; Alhabeeb, 2018; Aljaber, 2018). Saudi Arabia made significant progress in e-learning even before the outbreak of the Covid-19 pandemic via multiple initiatives, including e-learning deanships at universities, e-learning centers, the National Center of E-learning and Distance Learning (NCEL), and the e-learning sector in the Ministry of Education (MoE). Moreover, King Abdulaziz University and Saudi Electronic University offer bachelor's degrees online. These initiatives and sectors promote and follow up e-learning and distance education at schools and universities. It is also a government approach to integrate e-learning in Saudi Arabian higher education as part of the educational reforms referred to in 2030 Vision.

After the emergence of the Coronavirus, the learning process at Saudi universities shifted directly to e-learning using different educational platforms. The Blackboard LMS is one of the academic systems that has been officially and widely adopted for teaching-learning activities at most Saudi universities, including the University of Bisha, the context of this study (Aldiab et al., 2019; Aljuhney \& Murray, 2016; Asiri et al., 2012). It indicates that Saudi Arabia was ready for the e-learning process due to the available technical infrastructure and the academic community's awareness of the importance of e-learning as an emerging need.

\section{Student Satisfaction: An Overview}

Temizer and Turkyilmaz (2012) revealed that "student satisfaction and loyalty have attracted much attention in recent 
years and become one of the major goals of all educational institutions" (p. 3802). Bolliger and Erichsen (2013) defined student satisfaction as "the learner's perceived value of their educational experiences in an educational setting" (p. 5). It is one of the crucial factors that shape the success of the learning process, whether it is traditional or online. It is about the fulfillment of the students' interests and educational needs, which, in turn, are an integral part of the learning outcomes achievement.

This study depends on the SSI model, which according to Temizer and Turkyilmaz (2012), is "a structural model based on the assumptions that satisfaction is caused by some factors such as perceived quality, perceived value, expectations of students, and image of a firm" (p. 3803). Therefore, the SSI model was modified in this study based on the following justifications. In the present exceptional situation of the spread of the Covid-19 pandemic and the paradigm shift to e-learning, the image of the firm (i.e., the university), perceived value, and loyalty were out of the study concern. In other words, students are not 'customers' because all regular Saudi students in bachelor's programs at public universities are not charged tuition fees. As the study is off-campus, the physical aspects of the university facilities were not evaluated. It means that the situation and the context of the present study are different.

Figure 1 represents the perceived quality and expectations of the instructors' facilities and their design of the course contents, technical support, and their relationship with the students, all contributing to learners' overall satisfaction. The elements investigated in the instructors' facilities are motivation, encouragement, interaction, timely responses, and appreciation. The scale of the instructors' design of the course content includes good organization, easy access, teaching methods, content delivery, and recorded lectures. The technology dimension covers university support, training sessions, internet connection, university instructions, university social accounts, and academic services.

\section{Factors Affecting Student Satisfaction}

Many factors shape the multidimensional process of student satisfaction. Al-Juda (2017) revealed that "learning through virtual classrooms improves the satisfaction level of students

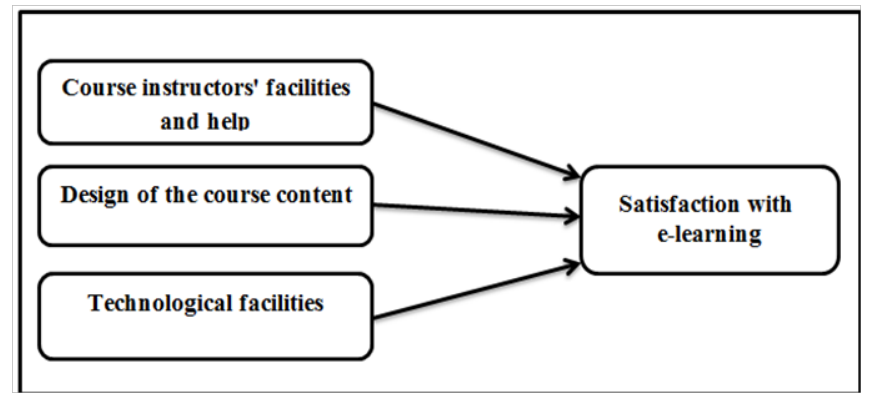

Figure 1: The proposed SSI Model as different aesthetic, interactive graphics, texts, sound, and video deeply engage the students" (p. 325). Dziuban et al. (2015) stated that "satisfied students appear to be engaged, motivated and responsive; contribute to an effective learning climate; achieve at higher levels" (p. 3). Stefanovic et al. (2011) found that instructor response timeliness, e-learning course flexibility, e-learning course quality, technology quality, internet quality, diversity in assessment, and interaction in the e-learning environment are critical factors affecting e- learners' satisfaction. Shea et al. (2003) argued that the instructional design and organization of the e-learning courses, instructors' direct interaction with students, and instructors' discourse facilitation are highly correlated with student satisfaction level in e-learning courses. The course content should be designed in a way that encourages a student's disciplined and consistent approach to work (Choy et al., 2002). These factors ensure students' higher satisfaction with the e-learning process, lead to more knowledge acquisition, and meet the learning outcomes. Otherwise, students and teachers alike will become dissatisfied with the e-learning process.

Scholars also confirmed that organization of learning activities, prompt and helpful communication with the instructor, clear guidelines concerning course expectations, enrollment support, student assignments, and requirements, and data security improve student satisfaction with online courses (Bates, 2019; Choy et al., 2002; Hara \& Kling, 1999; Vonderwell \& Turner, 2005). Carr-Chellman and Duchastel (2000), for example, stated that 'the essence of an online course is the organization of learning activities that enable the student to reach certain learning outcomes' (p. 233). Bates (2019) confirmed that a good quality design is associated with 'clear learning objectives, carefully structured content, controlled workloads for faculty and students, integrated media, relevant student activities, and assessment strongly tied to desired learning outcomes' (p. 167). Al-Fahad (2010) stated that the various ways of assessments in online learning are used to ensure the achievement of the learning outcomes. Well-designed, consistent, logically structured course content which is accompanied with easily accessible and downloadable learning materials, increases student satisfaction. Therefore, to ensure e-learners' higher satisfaction with the e-learning process, good preparation of course content and learning materials is needed. Otherwise, student dissatisfaction and frustration are inevitable as much as poor learning outcomes.

The e-learning process also needs to be communicative, depending on teacher-student interaction and using various audio and video materials, visual presentations, infographics, discussions, and different ways of assessment. Al Ghamdi (2017) stated that using up-to-date e-learning features can reduce the feeling of separation between students and lecturers within the distance education environment, can promote effective communication, and can improve the learning 
outcomes of students. Alkhalaf et al. (2013) reported that student dissatisfaction with online collaborative learning did not stem from a lack of available collaborative tools (i.e., chat rooms and discussion boards). Course instructors have a definite role in ensuring for their students a required level of interaction, involvement, and engagement in the learning process through the rich communication tools available on the Blackboard. Instructors' timely responses and technical support also satisfy students with the e-learning process.

Regarding the importance of technical support, Al-Juda (2017) stated that "the students' level of satisfaction regarding e-learning systems increases when they get easy access to technology" (p. 325). Most of the studies reported that the main issue that the students complain about is the internet connection (Al-Nofaie, 2020; Dahmash, 2020; Farrah \& Al-Bakry, 2020; Mahyoob, 2020). It denotes that low and unstable internet connectivity may lead to the e-learners' dissatisfaction with the e-learning process, especially for those who live in remote areas. Similarly, insufficient technical support from the concerned entities decreases the e-learners' satisfaction with the e-learning process.

Overall, Hara and Kling (1999) found that lack of quick feedback, technical problems, and ambiguous course instructions lead to student frustration and dissatisfaction. Lee, W. (2010) asserted that in the e-learning environment, universities are required to continually improve the quality of e-learning services to enhance student satisfaction. Being aware of these influential factors is crucial for better implementation and evaluation of the e-learning process.

\section{Previous Studies}

Aristovnik et al. (2020) examined how students in many countries globally perceive the impacts of Covid-19 on various aspects of their lives. The questionnaire results showed that students were most satisfied with the support provided by teaching staff and their universities. Still, deficient computer skills and the perception of a higher workload prevented them from perceiving their improved performance in the new teaching environment. Gender, type of work, education level, specialization, living standard, and country were critical factors influencing student satisfaction during the Covid-19 crisis.

Akuratiya and Meddage (2020) examined the Sri Lankan IT students' perception of online learning during the Covid19 pandemic. The questionnaire results showed that the respondents perceived online learning as favorable and as effective as face-to-face learning, enjoyable, effective in enabling them to learn at their own pace, easy to access online material, and ensuring active participation.

Xiong et al. (2020) examined the experience of students at Hong Kong University on the counts of effectiveness, challenges, and perceptions of the comparison between online courses and traditional face-to-face courses. The results showed that most respondents were dissatisfied with their online learning experiences during the Covid-19 pandemic due to their IT literacy and skills, low income, and unstable internet connection.

In the Indian context, Agarwal and Kaushik (2020) found that the medical students were interested and enjoyed using online sessions because they met their learning needs. However, technical faults were found to be a hindrance to their learning. On the other hand, Kaur et al. (2020) found that the medical respondents were not more satisfied with the e-learning-teaching process, but it was the need of the hour. Similarly, Abbasi et al. (2020) showed that the Pakistani medical and dental students had negative perceptions towards e-learning during the lockdown situation.

Three different studies, conducted in the Indonesian context, investigated university students' perception of online learning during the Covid-19 pandemic (Aji et al., 2020; Allo, 2020; Sujarwo et al., 2020). The questionnaire and interview results of these studies found that students generally had a positive perception of online learning and were interested in using it during the exceptional situation of the Covid-19 crisis. They found online learning helpful, flexible, beneficial, motivating, effective, autonomous, and easy to use. Poor internet connection, time consumption, and less experience were among the challenges they faced.

Malkawi et al. (2021) examined the satisfaction level and attitudes of students enrolled at United Arab Emirates University towards e-learning and virtual classes during the Covid-19 crisis. The questionnaire results indicated that student satisfaction and attitudes towards e-learning and virtual classes were high and positive during the pandemic. Students' gender, residential location, college, and GPA were not influential factors, but the educational level was.

In the Saudi context, some studies investigated students' perceptions, attitudes, and satisfaction with the e-learning process and the challenges they faced during the spread of the Covid-19 pandemic (Almekhlafy, 2020; Almelhi, 2021; Almusharraf \& Khahro, 2020; Alowedi, 2020; Dahmash, 2020; Elzainy et al., 2020). These studies concluded that the respondents were generally satisfied with and had positive attitudes towards the activities of the e-learning process. They also perceived benefitting from the e-learning process in developing their skills. Other studies revealed that the Saudi respondents were generally dissatisfied with the e-learning process (Al-Jarf, 2020; Al-Nofaie, 2020; Mahyoob, 2020). Respondents declared that e-learning was not always appealing, and they preferred traditional learning due to technical obstacles and decreased engagement and motivation. Technical challenges were the most cited obstacles faced by the respondents of these studies.

From the studies reviewed above, it can be deduced that most of these studies supported positivity and satisfaction 
with the e-learning process. Many factors affected positivity towards the e-learning process and the e-learners' satisfaction and attitudes, such as the instructors' facilities of engagement, encouragement, and easy access. Some other studies showed that the respondents were dissatisfied with the e-learning process due to technical obstacles, less motivation, and ways of evaluation. Generally, it can be stated that the e-learning process has revolutionized the learning process by showing hope to the academic world in the post-pandemic period. Therefore, it is hoped that with the students' obstacles are overcome, their opinions could change positively.

\section{Methodology}

\section{Characteristics of the Participants}

The population of the present study comprised the students enrolled at the University of Bisha in Saudi Arabia. The Deanship of Admission and Registration stated that the number of students in 2020-2021 was 15595 . The sample was 538 students who voluntarily took part in this study. It can be noted that the study sample is reasonably representative (Krejcie \& Morgan, 1970). The participants had at least one semester of cumulative experience in e-learning before and within the pandemic. Students were chosen to participate in this study as they are the cornerstone and the major players in the learning process, and they are the educationists' primary concern. Hence, their satisfaction with the e-learning process makes a difference and is critical for achieving the learning outcomes, especially during this exceptional situation generated by the Covid-19 pandemic. Table 1 summarizes the characteristics of the respondents.

\section{Research Instruments: Validity and Reliability}

Althobaiti and Mayhew (2015) emphasized that questionnaires are highly appropriate for the evaluation of LMS. First, the researcher developed a 31-item online questionnaire to meet the first three objectives of the study. An introductory paragraph stated the study objectives and guaranteed the respondents' anonymity and confidentiality. The respondents were asked to rate their satisfaction with the e-learning process based on their experiences. The first section comprised six items on the respondents' demographics of gender, academic campus, specialization, education level, residence place, and the tool(s) used to log in to the Blackboard (see Table 1). The second section identified the course instructors' facilities and help regarding e-learning (see Table 4). The third section investigated the quality and design of the course content (see Table 5). The fourth section elicited technical support provided to the respondents (see Table 6), and the last one measured the student satisfaction with the e-learning process (see Table 2). Sections 1-4 were measured with the fifth section of satisfaction.
The questionnaire statements were developed based on the review of the literature. To verify the validity of the questionnaire, the researcher sent the initial form of the questionnaire to five professors- two specializing in Research Methods and three in Distance Education. Consequently, the initial 45 items were compressed into 31 items based on the professors' suggestions for factor loading. A five-point Likert scale response matrix was used, ranging from (1) very dissatisfied to (5) very satisfied. Second, the infographic reports shared by the university were analyzed to meet the fourth objective through gaining deeper insights into the university's actions taken and facilities implemented to satisfy students and maximize a successful e-learning process.

The reliability of the questionnaire was established by administering the validated questionnaire as split half to 35 EFL learners at the same university where the actual survey was carried out. Cronbach's Alpha Coefficient found the instrument's reliability very high $(\mathrm{p}=.954)$.

\section{Data Collection and Analysis Procedures}

The researcher ensured ethical considerations before conducting the study. The scientific committee at the Deanship of Scientific Research at the University of Bisha approved the questionnaire (reference no. 46/54/26296). The questionnaire was translated into Arabic and designed using Google Forms. The teaching staff shared the questionnaire link with the respondents through the students' WhatsApp groups and on the Blackboard chatbox at the end of class time. Respondents' consent was also requested before filling the questionnaire by clicking on the icon 'Next' to commence participating in the study. The data collection process lasted for one month during the second semester of the 2020-2021 academic year.

SPSS (Version 26) was used to analyze the questionnaire data. Descriptive statistics (percentages, mean, and standard deviation) were used to get a clear image of the participants' responses. The data were normally distributed, so the parametric statistical techniques of independent-sample t-test, one-way analysis of variance (ANOVA), Pearson's correlation coefficient, and linear multiple regression analysis were used to analyze the responses. T-test and ANOVA were run to identify the statistically significant differences among the categorical variables with student satisfaction. Pearson's correlation coefficient was also run to examine the correlation between the scales. The multiple regression analysis was used to explore the total variance in student satisfaction with e-learning that could be explained by the three factors of instructors' facilities, design of the course content, and technology facilities. It was also used to identify the best predictor of student satisfaction with the e-learning process.

Four infographic reports about the progress of the e-learning process were gathered from the official website of the University of Bisha, www.ub.edu.sa, and its official account on 
Table 1: Descriptive statistics of the respondents' characteristics

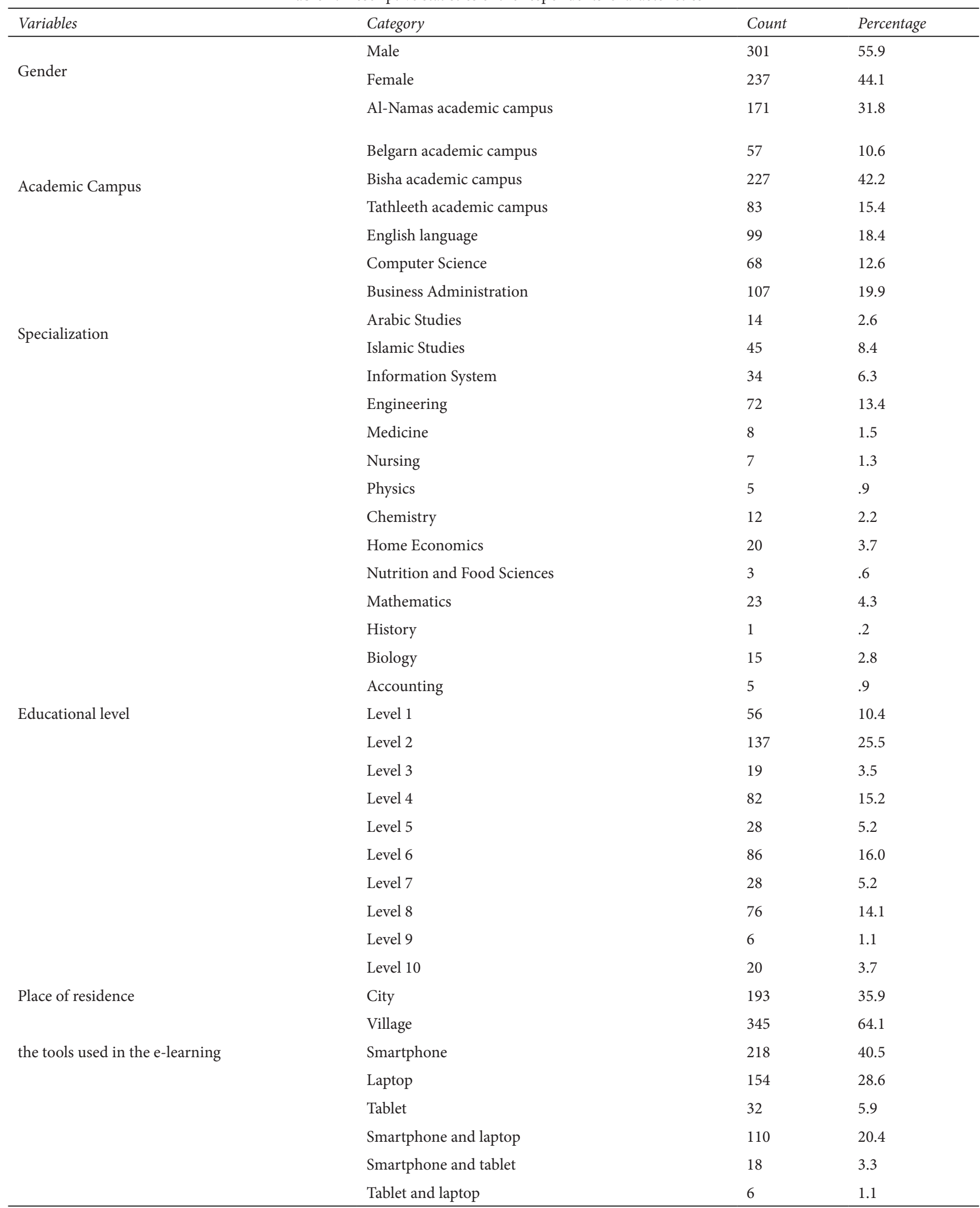


Twitter https://twitter.com/Bisha U. These reports reflected an inventory of the university facilities and activities implemented to enhance the progress of the e-learning process within one year. They showed the university's training sessions, virtual classes, LMS, and technical support. They were analyzed using content analysis. The questionnaire results and the infographic reports were triangulated.

\section{Results}

- RQ 1: To what extent are EFL learners satisfied with the e-learning process during the Covid-19 pandemic compared to students in other departments?

Table 2 shows that the respondents were generally very satisfied with the e-learning process during the pandemic $(\mathrm{M}=4.32, \mathrm{SD}=.874)$. Specifically, their high satisfaction was based on the easiness of the e-learning process $(M=4.41)$, the development of their experience in performing various activities on the Blackboard $(M=4.36)$, their peer interaction $(M=4.35)$, their acquired knowledge $(M=4.29)$, their GPA $(\mathrm{M}=4.27)$, and their acquired skills $(\mathrm{M}=4.26)$. Interestingly, as an indicator of the respondents' higher satisfaction with the e-learning process, more than half of the respondents (65.6\%) highly recommended e-learning implementation in the post-pandemic period $(M=4.25)$. It should also be noted that a considerable number of respondents $(9.5 \%)$ were very dissatisfied with the e-learning process. Figure 2 shows the percentages of the statements on the satisfaction scale.

To answer the first research question, it is clear in Table 3 that the respondents' satisfaction varied based on their specialization. As this study was mainly concerned with comparing EFL learners' satisfaction with students satisfaction in other departments, it was found that the respondents enrolled in departments of Islamic Studies, Foods and Nutrition Sciences, Medicine, Business Administration, Mathematics, Computer Science, Biology, Accounting, Arabic Language, Information System, and Chemistry were 'highly satisfied' with the e-learning process. On the other hand, students in the departments of Nursing, English language, Engineering, and Home Economics were 'satisfied with the e-learning process (See Table 3). Specifically, EFL learners enrolled in the English department (18.4\%) were 'satisfied' (M= $4.12, \mathrm{SD}=.952)$ with the e-learning process using Blackboard LMS compared to students in other departments (Islamic Studies till Chemistry) who were 'very satisfied.' ANOVA results in Table 8 found no statistically significant difference in the mean scores of the specialization with student satisfaction with the e-learning process $(\mathrm{F}=1.495, \mathrm{p}=.096)$. Therefore, the results generally confirmed that all respondents from different departments are satisfied with the e-learning process to varying levels as the mean scores fall within the satisfaction level $(\mathrm{M}=3.40$ - 5.00).

The results in Table 4 demonstrate that the respondents were 'satisfied' with the instructors' facilities and help ( $\mathrm{M}=$ $4.12, \mathrm{SD}=.90418)$. In other words, they were 'very satisfied' with the teachers' interaction $(M=4.33)$ and the timely responses to their questions $(M=4.20)$. On the other hand, the respondents were 'satisfied' with teachers' help to overcome

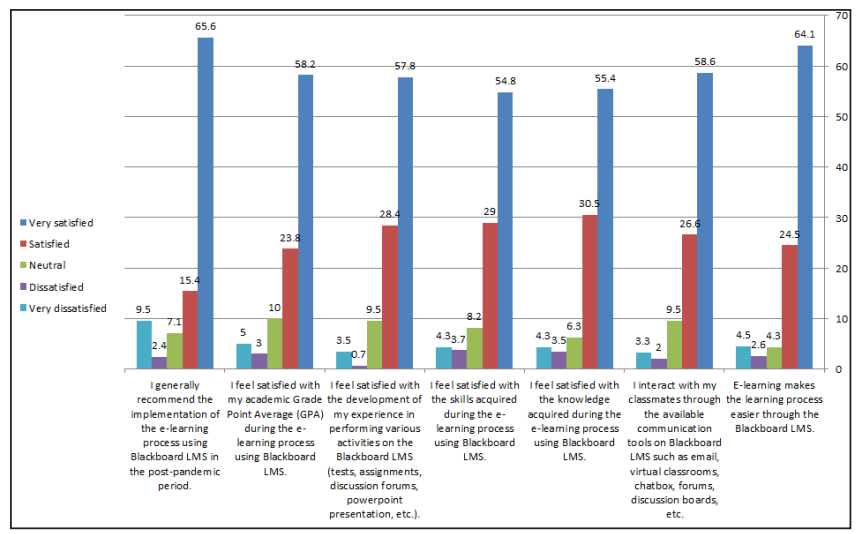

Figure 2: The distribution of the results of the general satisfaction scale (7 items)

Table 2: Descriptive statistics of the general satisfaction scale

\begin{tabular}{|c|c|c|c|}
\hline Satisfaction scale items & Mean & St. Deviation & Rank \\
\hline E-learning makes the learning process easier through the Blackboard LMS. & 4.41 & 1.011 & 1 \\
\hline $\begin{array}{l}\text { I interact with my classmates through the available communication tools on Blackboard LMS } \\
\text { such as email, virtual classrooms, chatbox, forums, discussion boards, etc. }\end{array}$ & 4.35 & 0.971 & 3 \\
\hline I feel satisfied with the knowledge acquired during the e-learning process using Blackboard LMS. & 4.29 & 1.030 & 4 \\
\hline I feel satisfied with the skills acquired during the e-learning process using Blackboard LMS. & 4.26 & 1.047 & 6 \\
\hline $\begin{array}{l}\text { I feel satisfied with the development of my experience in performing various activities on the } \\
\text { Blackboard LMS (tests, assignments, discussion forums, PowerPoint presentations, etc.). }\end{array}$ & 4.36 & 0.944 & 2 \\
\hline $\begin{array}{l}\text { I feel satisfied with my academic Grade Point Average (GPA) during the e-learning process using } \\
\text { Blackboard LMS. }\end{array}$ & 4.27 & 1.087 & 5 \\
\hline $\begin{array}{l}\text { I generally recommend the implementation of the e-learning process using Blackboard LMS in } \\
\text { the post-pandemic period. }\end{array}$ & 4.25 & 1.271 & 7 \\
\hline Total & 4.32 & .874 & \\
\hline
\end{tabular}


Table 3: Categories of the respondents' specializations

\begin{tabular}{lll}
\hline Specialization & Mean & Std. Deviation \\
\hline History & 5.00 &. \\
Islamic Studies & 4.63 & .740 \\
Foods and Nutrition Sciences & 4.52 & .436 \\
Medicine & 4.50 & .425 \\
Physics & 4.49 & .480 \\
Business Administration & 4.47 & .747 \\
Mathematics & 4.40 & .695 \\
Computer Science & 4.40 & .846 \\
Biology & 4.40 & .758 \\
Accounting & 4.37 & .799 \\
Arabic Language & 4.32 & .885 \\
Information System & 4.29 & .745 \\
Chemistry & 4.24 & .657 \\
Nursing & 4.14 & .617 \\
English & 4.12 & .952 \\
Engineering & 4.08 & 1.159 \\
Home Economics & 4.06 & .972 \\
\hline
\end{tabular}

Table 4: Descriptive statistics of the instructors' facilities and help scale

\begin{tabular}{|c|c|c|c|}
\hline Instructors' scale items & Mean & St. Deviation & Rank \\
\hline $\begin{array}{l}\text { The teacher motivates me to } \\
\text { participate actively during } \\
\text { the e-learning process on } \\
\text { Blackboard LMS. }\end{array}$ & 4.15 & 1.026824 & 4 \\
\hline $\begin{array}{l}\text { The teacher encourages me } \\
\text { to become actively involved } \\
\text { during the e-learning } \\
\text { process on Blackboard LMS. }\end{array}$ & 4.19 & 1.013209 & 3 \\
\hline $\begin{array}{l}\text { The teacher interacts with } \\
\text { me through the available } \\
\text { communication tools on } \\
\text { Blackboard LMS such as } \\
\text { email, virtual classrooms, } \\
\text { chat box, forums, discussion } \\
\text { boards, etc. }\end{array}$ & 4.33 & 0.920254 & 1 \\
\hline $\begin{array}{l}\text { The teacher responds to my } \\
\text { questions timely during the } \\
\text { e-learning process. }\end{array}$ & 4.23 & 1.053786 & 2 \\
\hline $\begin{array}{l}\text { The teacher appreciates } \\
\text { my conditions during the } \\
\text { Covid-19 pandemic. }\end{array}$ & 3.92 & 1.310370 & 6 \\
\hline The teacher helps me & 3.93 & 1.218507 & 5 \\
\hline
\end{tabular}
overcome the technical problems in the e-learning process.

Total $\quad 4.12 \quad .904$

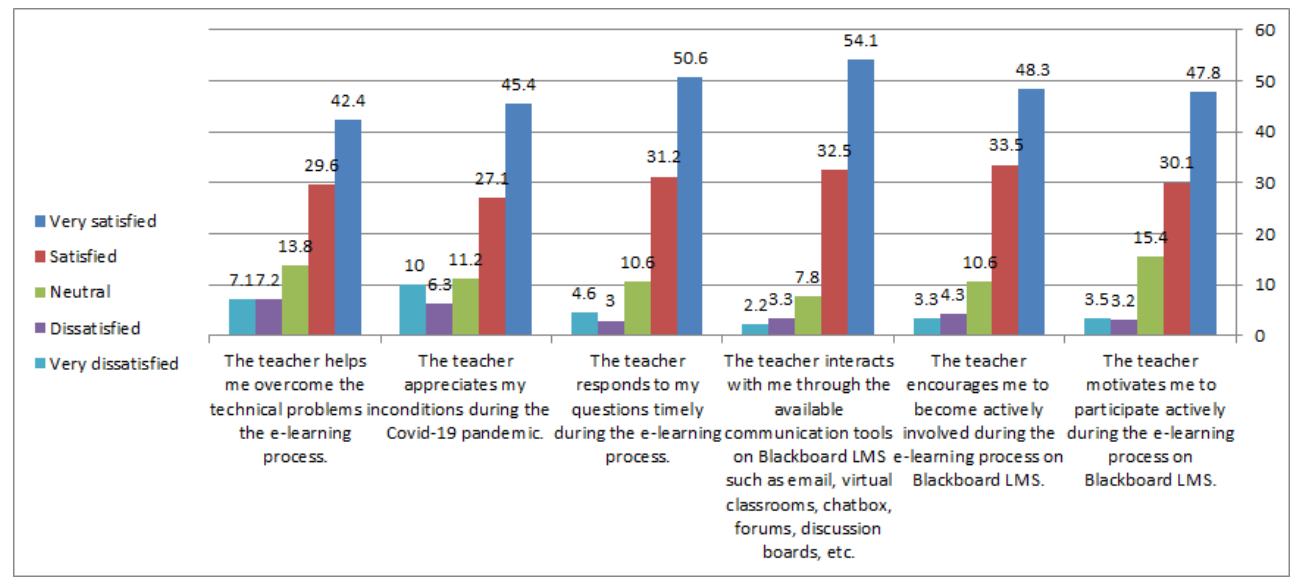

Figure 3: The distribution of the results of the instructors' facilities scale (6 items)

the technical issues $(M=3.929)$ and the appreciation of their exceptional conditions during the Covid-19 pandemic ( $\mathrm{M}=$ 3.92). Figure 3 represents the percentages of the instructors' facilities statements.

The results in Table 5 show that the respondents were generally 'very satisfied' with the design of the course content and educational materials uploaded on the Blackboard during the Covid-19 pandemic $(\mathrm{M}=4.32, \mathrm{SD}=.765)$. Specifically, the respondents were 'very satisfied' with the easy access to the course content $(M=4.44)$, the teachers' employment of the various ways of assessments $(M=4.43)$, and the teachers' recording of lectures $(M=4.39)$. Figure 4 shows the distribution of the results of the course content scale.

Table 6 shows that the respondents were generally 'satisfied' with the technical facilities and support during the Covid-19 pandemic $(M=4.00, S D=.954)$. Specifically, the respondents were 'very satisfied' with the university academic e-services $(M=4.21)$ and the university instructions regarding the e-learning process $(\mathrm{M}=4.19)$. On the other hand, they were 'satisfied' with the speed of the internet connection $(M=3.53)$ and with the university support when they faced technical problems on the Blackboard $(M=3.92)$. Figure 5 
Table 5: Descriptive statistics of the course content scale (6 items)

Course content scale items Mean

St. Deviation

1.029

0.887

1.103

1.004

0.952

0.873

4.39

The teacher records the lectures on Blackboard LMS to be accessible later on at any time

The teacher employs various ways of assessment such as tests, quizzes, assignments, participation, 4.43 presentations, activities, etc.

Total

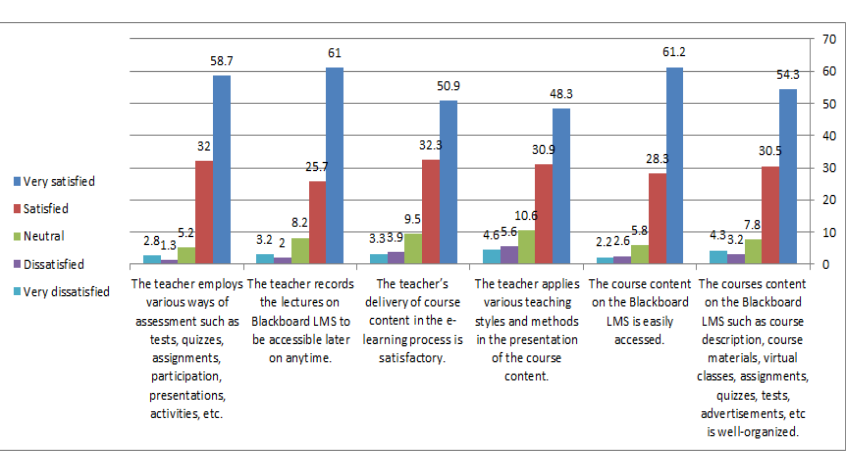

Figure 4: The distribution of the results of the course content scale ( 6 items)

4.32

.765

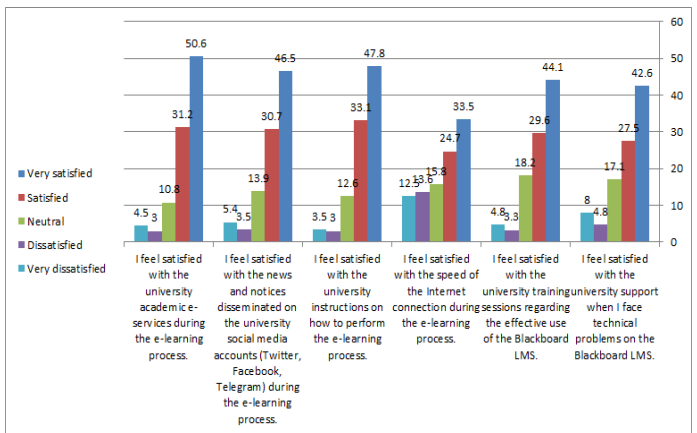

Figure 5: The distribution of the results of the technology dimension scale ( 6 items)

Table 6: Descriptive statistics of the technology dimension scale

\begin{tabular}{|c|c|c|c|}
\hline Technical scale items & Mean & St. Deviation & Rank \\
\hline $\begin{array}{l}\text { I feel satisfied with the university's support when I face technical problems on the Blackboard } \\
\text { LMS. }\end{array}$ & 3.92 & 1.227 & 5 \\
\hline $\begin{array}{l}\text { I feel satisfied with the university training sessions regarding the effective use of the Blackboard } \\
\text { LMS. }\end{array}$ & 4.05 & 1.092 & 4 \\
\hline I feel satisfied with the speed of the internet connection during the e-learning process. & 3.53 & 1.393 & 6 \\
\hline I feel satisfied with the university instructions on how to perform the e-learning process. & 4.19 & 1.004 & 2 \\
\hline $\begin{array}{l}\text { I feel satisfied with the news and notices disseminated on the university's social media accounts } \\
\text { (Twitter, Facebook, Telegram) during the e-learning process. }\end{array}$ & 4.09 & 1.106 & 3 \\
\hline I feel satisfied with the university academic e-services during the e-learning process. & 4.21 & 1.046 & 1 \\
\hline Total & 4.00 & .954 & \\
\hline
\end{tabular}

represents the distribution of the results of the technology scale.

To summarize, the results show that the respondents' high satisfaction with the e-learning process $(M=4.32)$ was specifically based on the statements of the well-developed and easy access to course content and educational materials $(\mathrm{M}=$ 4.44), the teachers' employment of various ways of assessments $(M=4.43)$, the teachers' interaction with their students $(M=$ $4.33)$, timely responses to the students' inquiries $(M=4.20)$, and the university academic e-services $(M=4.20)$.

On the other hand, the respondents were 'satisfied' with the e-learning process using the Blackboard during the Covid-19 pandemic due to the teachers' encouragement
$(M=4.19)$, motivation $(M=4.15)$, technical help (M. 3.93), and appreciation $(M=3.92)$. Moreover, they were 'not highly satisfied' with the teachers' employment of various teaching styles and methods used in the virtual classes $(\mathrm{M}=$ 4.13). Technical issues constitute the main challenge to the e-learning process. The respondents were 'less satisfied' with the university training sessions regarding the effective use of the Blackboard $(M=4.05)$, the university technical support $(M=3.92)$, and the speed of the internet connection $(M=3.53)$.

Overall, the respondents were 'very satisfied' with the e-learning process $(\mathrm{M}=4.32, \mathrm{DS}=.874)$ and with the course content design $(\mathrm{M}=4.32, \mathrm{DS}=.765)$. Similarly, they were only 'satisfied' with the instructors' facilities and help ( $\mathrm{M}=$ 
4.12, $\mathrm{DS}=.904)$ and the technology dimension $(\mathrm{M}=4.00$, $\mathrm{DS}=.954)$.

- RQ2: Are there statistically significant differences between gender, academic campus, specialization, education level, place of residence, and the tool used to log in the e-learning process and student satisfaction with the e-learning process?

The t-test and ANOVA parametric statistical techniques were run to answer the second question. First, the t-test compared the gender and residence place scores with the respondents' level of satisfaction with the e-learning process. The results in Table 7 report that there was no statistically significant difference in the student satisfaction scores for males $(\mathrm{M}=4.34, \mathrm{SD}=0.906)$ and females $(\mathrm{M}=4.28, \mathrm{SD}=$ 0.833 ; $\mathrm{t}(0.744), \mathrm{p}=0.457)$. Similarly, there was no statistically significant difference in the student satisfaction scores for students who lived in cities $(\mathrm{M}=4.28, \mathrm{SD}=0.905)$ and those who lived in villages $(\mathrm{M}=4.33, \mathrm{SD}=0.858 ; \mathrm{t}(-0.609), \mathrm{p}=0.543)$.

Second, Levene's test found that the assumption of homogeneity of variance was not violated (Sig= .116, $\mathrm{p}>.05$ ). Hence, ANOVA explored the impact of the respondents' academic campus, specialization, educational level, and the devices used in the learning process on the respondents' level of satisfaction with the e-learning process. The results in Table 8 show that there were no statistically significant differences in the mean scores of academic campus $(\mathrm{F}=1.699, \mathrm{p}=.166)$, specialization $(\mathrm{F}=1.495, \mathrm{p}=.096)$, and the devices used in the learning process $(\mathrm{F}=1.939, \mathrm{p}=.086)$ with the respondents' satisfaction with the e-learning process as ( $\mathrm{p}>.05)$. There was, however, a statistically significant difference in the mean scores of the respondents' educational level only $(\mathrm{F}=2.684, \mathrm{p}=.005)$. The Tukey HSD test indicated that the mean score for Group 2: Level $2(\mathrm{M}=4.49, \mathrm{SD}=.688)$ was significantly different from Group 8: Level $8(\mathrm{M}=4.09, \mathrm{SD}=1.055)$. Other groups did not differ significantly from either Group 2 or 8.
To answer the second research question, it can be noted that the socio-demographic factors of gender, academic campus, specialization, place of residence, and the tool used to log in the e-learning process did not affect student satisfaction with the e-learning process. Only the educational level factor was influential on the respondents' satisfaction with the e-learning process using Blackboard during the Covid-19 pandemic.

- RQ 3: Which is the best predictor of student satisfaction with the e-learning process?

Pearson correlation and multiple regression analysis were run to answer the third research question. Pearson correlation showed that there was a strong positive correlation between student satisfaction and the predictive factors of course instructors' facilities and help (.756), technology dimension (.726), and the course content design (.724). It denotes that the strongest positive correlation was between student satisfaction and the course instructors' facilities and help.

The linear multiple regression analysis reported that the correlation between the three predictive factors with student satisfaction was $(\mathrm{R}=.791)$. The results in Table 9 reveal that these factors explained $62.5 \%$ of the variance in student satisfaction with the e-learning process, which can be considered satisfactory. By referring to the $\mathrm{F}$ value and its $\mathrm{P}$ value, it can be said that the model is valid and that there is a correlation between respondents' e-learning satisfaction and the three predictive factors. A multicollinearity test was carried out to verify the existence of the mentioned relationship. The results show that the Variance Inflation Factor (VIF) of the model was 3.712, indicating the non-existence of multicollinearity problems. In addition, the coefficient data output and ANOVA confirmed the statistically significant differences in the mean scores of the three predictive factors and the students' e-learning satisfaction $(\mathrm{p}<.01=.0000)$. It denotes that the three predictive factors made a unique and statistically significant contribution to student satisfaction.

Table 7: Significant differences of gender and place of residence with the satisfaction dimension using t-test

\begin{tabular}{llllllll}
\hline & Category & $N$ & $M$ & $S D$ & $t$ & $F$ & Sig. (2-tailed) \\
\hline Gender & Male & 301 & 4.3398 & 0.90647 & 0.744 & 1.336 & 0.457 \\
& Female & 237 & 4.2833 & 0.83268 & & 0.685 & 0.543 \\
Place of & City & 193 & 4.2842 & 0.90503 & -0.609 & & \\
residence & Village & 345 & 4.3321 & 0.85761 & & & \\
\hline
\end{tabular}

Table 8: Significant differences of more than two-group variables using ANOVA

\begin{tabular}{llll}
\hline & Category & F & Sig. (2-tailed) \\
\hline \multirow{2}{*}{ Satisfaction with the e-learning process } & Academic campus & 1.699 & .166 \\
& Specialization & 1.495 & .096 \\
& Educational level & 2.684 & $.005^{*}$ \\
& Tools used in the e-learning & 1.939 & .086 \\
\hline
\end{tabular}

ॠThe mean difference is significant at the 0.05 level. 
Student Satisfaction with E-learning

Table 9: The results of the multiple regression analysis

\begin{tabular}{|c|c|c|c|c|c|c|c|c|}
\hline The dependent variable & Factors & $R$ & $R 2$ & $F$ & Sig. & Beta & $t$ & VIF factor \\
\hline \multirow{3}{*}{$\begin{array}{l}\text { Satisfaction with the e-learning } \\
\text { process }\end{array}$} & Instructors' facilities and help & & & & & .379 & 7.43 & 3.712 \\
\hline & Course content dimension & & & & & .214 & 4.27 & 3.585 \\
\hline & Technology dimension & .791 & .625 & 296.60 & 0.000 & .252 & 5.21 & 3.338 \\
\hline
\end{tabular}

Table 10: Statistics of the training sessions conducted by the University of Bisha

\begin{tabular}{|c|c|c|c|c|c|}
\hline 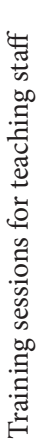 & 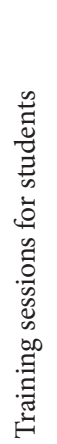 & 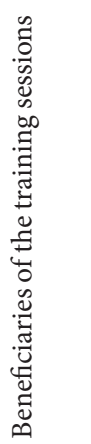 & 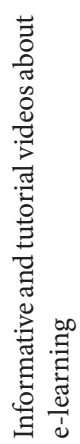 & 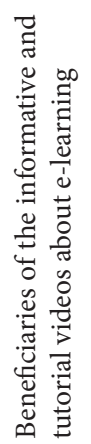 & 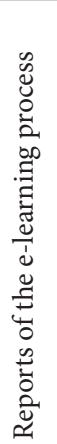 \\
\hline 87 & 48 & 14572 & 34 & 8754 & 231 \\
\hline
\end{tabular}

More importantly, the instructors' facilities and help factor made the strongest unique contribution to students' e-learning satisfaction (beta $=.379$ ).

- RQ4: What are the university facilities and services preexisting or incorporated to enhance student satisfaction with the e-learning process during the spread Covid-19 pandemic?

This section exposes the statistical reports of a one-year e-learning experience at the University of Bisha from 1st March 2020 to 28th February 2021, following the university's lockdown and the transition to online learning. These reports were shared on the University website https://cutt.us/TGQzc, and its official account on Twitter: https://twitter.com/ Bisha U/status/1369913629139738624.

Regarding the training sessions, the university qualified 14572 instructors and students to ensure the smooth flow of the learning process and the high quality of online courses. On the one hand, 87 training sessions were conducted for the course instructors to create clear and accessible icons in the content areas like course prescription, lectures, virtual classes, contact information, assignments, tests, students' grading, and announcements. These training sessions also considered the midterm and final exam regulations and techniques for the course instructors to apply before, while, and after preparing the question pools. On the other hand, 48 training sessions were performed to train students on logging the Blackboard platform, attend virtual classes, shift between courses, submit assignments, participate in discussion boards and wikis, overcome technical problems, send technical support tickets, sit for exams, and know their grades. Students were also trained on the regulations and techniques that guarantee problemfree exams. The recordings of the training sessions and short tutorial videos were also shared on the university YouTube channel 'ta'allam' 'learn': https://www.youtube.com/channel/ UCgEsQ1PTUot2igIp0NQy8GA/videos

To minimize the students' social isolation, the Students' Affairs Deanship organized many sessions on building students' personalities and preparing them for the workplace with sessions on cyber security, solving problems creatively, social and emotional intelligence, critical thinking, academic excellence skills, skills for handling tests and reducing the associated anxiety, and personal planning. Regarding the virtual classes system, the university reported that the course instructors created 139983 virtual classes during one year of e-learning. Table 11 represents the number of sessions created, the number of attendees, and the duration of these sessions. Moreover, most of the sessions ( $\mathrm{n}=105997)$ were recorded in which absentees or those who logged out because of technical problems could watch these classes later. It indicates that the university exerted its utmost efforts to guarantee the continuity of the learning process directly after the university's physical closure.

Table 12 shows the information on the Blackboard LMS at the university. Specifically, the number of students who logged in to the Blackboard was 3,084,700. The number of the available files on the Blackboard was 124,859. The number of the discussion boards was 210,979, and the number of the assessments was 2,041,754. These results made it clear that the students regularly attended the classes. Students can also surf the uploaded files and discussion boards anytime anywhere. The variety of assessment ways enables the course instructors to assess the learning outcomes.

Students complained about facing technical problems, especially those who lived in remote or geographically scattered areas where the internet connection is weak or unstable. Table 13 shows that the Deanship of E-learning and Distance Education (DEDE) employed various communication tools (direct calls, technical support e-tickets, WhatsApp messages, and emails) to respond to the students' and teachers' technical support requests. The total requests for technical support were 24,827, distributed between 6,820 e-tickets, 4,527 calls, 12,482 WhatsApp messages, and 998 emails. Students used WhatsApp messages to ask for technical support more frequently as they are instant, handy, and low-cost. Moreover, the DEDE circulated frequent infographics and tutorial 
Table 11: Statistics on the distance learning at the University of Bisha: Virtual classes system

\begin{tabular}{|c|c|c|c|}
\hline 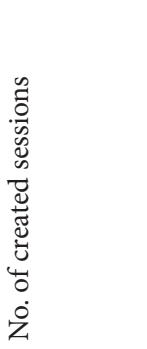 & 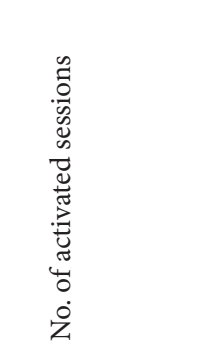 & 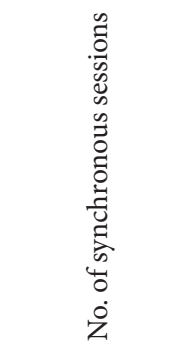 & 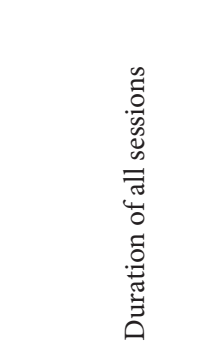 \\
\hline 139983 & 425464 & 47040 & 13072,8 \\
\hline \multicolumn{4}{|c|}{ Table 12: Statistics on the Blackboard LMS at the University of Bisha } \\
\hline $\begin{array}{l}\text { No. of login } \\
\text { processes }\end{array}$ & $\begin{array}{l}\text { No. of available } \\
\text { files }\end{array}$ & $\begin{array}{l}\text { No. of } \\
\text { discussion } \\
\text { boards }\end{array}$ & $\begin{array}{l}\text { No. of } \\
\text { assessments }\end{array}$ \\
\hline 3084700 & 124859 & 210979 & 2041754 \\
\hline
\end{tabular}

videos on avoiding technical problems like tackling internet connection and logging out the virtual classes or exams. It indicates that the DEDE made considerable efforts and a continuous follow-up to tackle technical issues.

Moreover, the university activated various processes electronically like academic services on the students' website, the Beneficiary Care Center, and the Academic Guide. Furthermore, the university is used to organize a one-week program at the beginning of each semester to welcome the freshmen. It showed presentations on the study regulations and rules, adaptation to university life, and instructions on logging in to the academic website and the Blackboard platform. It adapted new teaching styles and assessment methods to meet the students' needs, considering the exceptional situation of the Covid-19 spread, the nature of the courses, and the learning programs. Daily, weekly, monthly, and semester follow-up reports were also reported to the higher authority for evaluating the progress of the e-learning process.

Overall, the respondents' satisfaction with the e-learning process can be classified into two groups based on their specialization. The first group was those who were 'very satisfied'. It included most of the respondents who were enrolled in the departments of Islamic Studies, Foods and Nutrition Sciences, Medicine, Physics, Business Administration, Mathematics, Computer Science, Biology, Accounting, Arabic Language, Information System, and Chemistry. It was clear that most of the respondents were 'very satisfied' with the e-learning process. The second group was those who were only 'satisfied'. It included respondents enrolled in the departments of Nursing, English language, Engineering, Home Economics. The EFL learners fell within the second group in which they were only 'satisfied' with the e-learning process using Blackboard LMS.

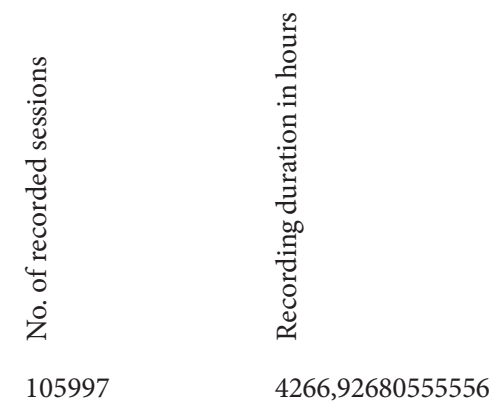

Table 13: Statistics on technical support processes at the University of Bisha

\begin{tabular}{lllll}
\hline E-tickets & Calls & $\begin{array}{l}\text { WhatsApp } \\
\text { Message }\end{array}$ & E-mails & $\begin{array}{l}\text { Total of technical } \\
\text { support }\end{array}$ \\
\hline 6820 & 4527 & 12482 & 998 & 24.827 \\
\hline
\end{tabular}

Moreover, the socio-demographic factors of gender, residence place, academic campus, specialization, and the device(s) used in the learning process did not affect student satisfaction with the e-learning process. Only the educational level made a difference in student satisfaction with the e-learning process. Further, instructors' facilities and help, technology dimension, and design of the course content were strongly correlated with student satisfaction. Specifically, the instructors' facilities and help was the best predictive factor that made the strongest unique contribution to student satisfaction with the e-learning process.

The infographic reports also showed that the University of Bisha, represented by its concerned deanships, initiated strategic plans to ensure the continuity and smooth flow of the learning process. These reports indicated that the university facilities and services (e.g., training sessions, academic and administrative services, technical support, and study instructions and regulations) positively affect student satisfaction with the e-learning process during the Covid-19 spread. These services helped students overcome the problems that could hinder the success of the learning process. These results also uncovered a match between the participants' questionnaire responses and the information disseminated in these reports.

\section{Discussion}

\section{Student satisfaction with the e-Learning Process}

The results showed that e-learners enrolled in departments of Islamic Studies, Foods and Nutrition Sciences, Medicine, Physics, Business Administration, Mathematics, Computer Science, Biology, Accounting, Arabic Language, Information System, and Chemistry were very satisfied with the e-learning 
process using Blackboard LMS during the Covid-19 pandemic. Similarly, E-learners enrolled in departments of Nursing, English language, Engineering, and Home Economics were satisfied with the e-learning process. The EFL learners fell within this group in which they were satisfied with the e-learning process using Blackboard LMS during the Covid-19 pandemic. It can be justified that the social science fields like Islamic studies, Arabic studies, and business administration are primarily theoretical. In other words, EFL students need to develop their language skills, especially listening and speaking, in person, when they interact with their teachers and peers on campus. Other courses like English Pronunciation, Speech Workshop, Phonetics, Phonology, and Field Experience depend on the physical attendance of students. Technical problems and the instructors' low appreciation of the exceptional situation of the Covid-19 crisis might also play a critical role in shaping their satisfaction. Generally, EFL learners were satisfied with the e-learning process, but their satisfaction was not to the expected level when compared with the satisfaction of students enrolled in other departments. As the researcher is the academic registrar of the college and has access to students' information, it was noticed that students' GPAs were higher than their GPAs in the pre-pandemic period. This observation could also be another indicator of student satisfaction with the e-learning process.

These results were consistent with the results of the previous studies conducted in various contexts with respondents enrolled in different departments (Agarwal \& Kaushik, 2020; Aji et al., 2020; Akuratiya \& Meddage, 2020; Almekhlafy, 2020; Almusharraf \& Khahro, 2020; Alowedi, 2020; Aristovnik et al., 2020; Dahmash, 2020; Elzainy et al., 2020; Farrah \& Al-Bakry, 2020; Malkawi et al., 2021; Sujarwo et al., 2020). The respondents of these studies were satisfied with the e-learning process during the Covid-19 pandemic. They perceived e-learning as satisfactory, effective, interesting, and enjoyable. They have also achieved learning outcomes. Moreover, the results of these studies went in line with the results of the present study in which many factors contributed to the respondents' satisfaction and positive attitudes towards the e-learning process like the different ways of assessment, the well-designed course content, the instructors' performance and interaction, technical support, and the various teaching methods and styles.

\section{Factors Affecting Student Satisfaction}

The results showed that the socio-demographic factors of gender, residence place, academic campus, specialization, and the devices used in the learning process did not affect student satisfaction with the e-learning process. It can be attributed to the university and the course instructors' significant effort and services that led to student satisfaction regardless of the influence of these factors. The influential factors examined in the present study were inconsistent with the results of Aristovnik et al. (2020). Training sessions, technical support, various assessments, and academic e-services might bridge the pitfalls and leave no room for such differences. As the learning is online, students also have the same facilities and opportunities regardless of differences.

The educational level made a difference in student satisfaction with the e-learning process. Moreover, instructors' facilities and help, technology dimension, and design of the course content were strongly correlated with student satisfaction. Interestingly, instructors' facilities and help made the strongest unique contribution to student satisfaction with the e-learning process. It indicates that course instructors' motivation, encouragement, mutual interaction, help in overcoming technical obstacles, and their timely response increases student satisfaction with the e-learning process and hence led to a successful learning process.

In several areas, the results of this study were inconsistent with the results of the previous studies (Abbasi et al., 2020; Agarwal \& Kaushik, 2020; Aji et al., 2020; Al-Jarf, 2020; Al-Nofaie, 2020; Dahmash, 2020; Farrah \& Al-Bakry, 2020; Kaur et al., 2020; Mahyoob, 2020; Xiong et al., 2020). The respondents of these studies were dissatisfied with online learning due to many factors, among them were the technical problems they faced, unstable internet connection, less experience, lack of physical interaction, instructors' performance, the need for training, difficulties with online tests, and the unreliable evaluation system.

Concerning the results of the present study, it could be stated that course instructors and the university entities have an essential role in changing students' perceptions and opinions regarding their satisfaction with the e-learning process. They tried to tackle and minimize the problems mentioned in the previous studies by introducing many facilities. The well-designed course content and educational materials played a critical role in increasing the e-learners' satisfaction. Specifically, the course instructors received extensive training on the effective use and employment of the Blackboard icons. They prepared the contents on the Blackboard icons before the beginning of each semester to ensure the uploaded materials' flexibility, clarity, interactivity, and accessibility. The assigned university reviewers reviewed the Blackboard content area and the application of exam instructions. Activating these areas and icons increased student satisfaction with the e-learning process using Blackboard LMS during the Covid-19 pandemic.

The course instructors also minimized students' feelings of isolation through mutual interaction and engagement via synchronous and asynchronous communication channels (audio and video calls on the Blackboard, chatbox, discussion boards, forums, wikis, and emails). Instructors and academic advisors were also approachable when needed via direct calls, WhatsApp and Telegram groups, or time-flexible academic 
counseling and office hours virtual sessions. These strategies are also applied for peer interaction.

Moreover, the university facilities and support mentioned so far contributed to shaping the students' opinions and satisfaction. It made significant efforts to tackle the technical problems through timely responses to the various communication channels of e-tickets, calls, WhatsApp messages, and emails. Also, to avoid pressure on the network, especially at peak time, the Deanship of Admission and Registration at the University of Bisha prepared well-planned study and final exam timetables in which the students' classes and final exams were at different shifts (in the morning, in the afternoon, and at night). Moreover, course instructors were requested to record their classes in which the absentees and those who complained about technical problems or poor internet connection could access the recordings later. Despite these facilities, some students still suffered from technical issues. Students' complaints could be due to low internet connectivity and the pressure on the internet network, particularly during peak time. It was also found that more than half (64.1\%) of the respondents lived in rural areas. In addition to other devices, $40.5 \%$ of the respondents used cellphones to $\log$ in to the Blackboard, which could be one of the reasons for technical difficulties during the learning process. Small smartphone screens, incoming calls, and synchronous opening of other applications and websites could also cause technical issues, particularly during virtual classes and exams.

Regarding the test and evaluation system, the formative assessment was adopted after the spread of the Covid-19 pandemic, depending on various in-progress activities, assignments, and quizzes. The summative assessments mentioned in the course prescriptions like oral tests, presentations, participation, mid and final exams, assignments, discussion boards, quizzes, and activities were followed in 2020-2021, depending on the nature of the different courses and the university regulations and instructions. Many procedures were applied to guarantee well-designed and acceptable ways of assessment and minimize the chance of cheating and malpractices. These procedures included using the question pools, the randomization of the questions and answers, a oneby-one show of questions, not allowing students to go back to the submitted answers, specific time for the exam, hiding the exam icon after the due date, and hiding the questions' responses till the end of due time. The assigned university reviewers also reviewed the exam instructions and regulations before the exam date in 48 hours. Teachers were also ready to reply to any complaint regarding the exam regulations during exam time. Exam instructions and regulations were also disseminated to the students before exam time. Generally, the university and course instructors' procedures could justify the results of this study and the reasons why they are different from the previous ones conducted in other contexts.

\section{Conclusion}

Student satisfaction with the e-learning process is an indicator of its success, effectiveness, and acceptability. Traditional learning has smoothly transferred to e-learning within one day after the declaration of the lockdown of the academic institutions. E-learning has suddenly become an indispensable solution to guarantee the continuity of the learning process in the pandemic period.

This study aimed to identify the extent to which the EFL learners were satisfied with the e-learning process during the Covid-19 pandemic compared to students in other departments based on the impacting determinants of university facilities and services such as instructors' help, course designs, and technical support on their satisfaction. The questionnaire and infographic reports were used to meet the objectives mentioned above. After collecting the data from the e-learners enrolled in the different departments of the University of Bisha in Saudi Arabia, the present study comes to the following main findings:

- E-learners enrolled in the departments of Islamic Studies, Foods and Nutrition Sciences, Medicine, Physics, Business Administration, Mathematics, Computer Science, Biology, Accounting, Arabic Language, Information System, and Chemistry were very satisfied with the e-learning process using Blackboard LMS during the Covid-19 pandemic.

- E-learners enrolled in the departments of Nursing, English language, Engineering, and Home Economics were only satisfied with the e-learning process. Specifically, the EFL learners fell within this group as they were only satisfied with the e-learning process using Blackboard LMS during the Covid-19 pandemic.

- The socio-demographic factors of gender, residence place, academic campus, specialization, and the devices used in the learning process did not affect student satisfaction with the e-learning process. Only the educational level made a difference in student satisfaction with the e-learning process. Furthermore, the course instructors' facilities, the course content design, and the technology dimension were predictive factors that affect student satisfaction with the e-learning process. Specifically, the course instructor scale was the best predictor of the respondents' satisfaction with the e-learning process.

- The concerned deanships at the University of Bisha, namely DEDE, have established many strategic plans and services that ensure the innovative implementation of the e-learning process, the achievement of the learning outcomes, and the success of the learning process.

- Technical issues and instructors' lack of appreciation of the exceptional situation were among the factors that lessened the e-learners' satisfaction with the e-learning process. 
To summarize, it can be stated that the Covid-19 pandemic has stimulated a massive educational change. It has uncovered the readiness of Saudi academic institutions, including administrations, teaching staff, and students who were well prepared for the sudden transition to study online via the Blackboard. Course instructors exerted their utmost efforts to create well-designed course content and materials. Facilities on the Blackboard are compatible with traditional learning facilities as there are many icons for virtual classes, actual participation, mutual interaction, uploading assignments and activities, sitting for exams, and tracking grading centers. Communication channels were made ready to tackle the teachers' and students' technical issues. Training sessions were conducted for the teachers and students to meet their diverse needs. Regulations and instructions, recorded sessions, and tutorial videos were also shared on the university's official websites and channels. Many academic and administrative services were also activated online. These effective facilities increased the e-learners' satisfaction, minimized the influential factors on their satisfaction, and overall ensured the success of the learning process.

\section{LIMITATIONS}

This study has some limitations that could be addressed in future research. It was conducted in one Saudi university, the University of Bisha, so the results could be generalized with caution as other universities have cumulative experience in the implementation of e-learning before the pandemic. Therefore, future studies could also investigate the e-learning satisfaction of students at other universities. They could also study instructors' and policymakers' opinions regarding their performed facilities, strength and weaknesses of e-learning, and its possible implementation in the post-pandemic period.

\section{Implications and Recommendations}

The application of the e-learning process is promising and is expected to be the forthcoming trend in at least some courses. Hence, the results of this study lead to a better understanding of students' perceptions and satisfaction with e-learning, the influential factors affecting this process, and the university strategies implemented for ensuring successful e-learning. It constitutes a basis for further studies about the e-learners' satisfaction with the e-learning process. The smooth transition to the e-learning process in the current unprecedented situation resulted from the shared collaboration of the concerned entities, including universities, teachers, and students. The e-learning process has come to stay with some weak areas to be strengthened. Despite the initiatives and the steady steps taken to satisfy students, they will be more satisfied if the concerned people and stakeholders met and appreciated their interests and academic concerns. Therefore, to maximize and promote student satisfaction with and benefits from the new experience of e-learning, it is recommended to the Saudi universities represented by the e-learning deanships to meet the learning needs and expectations of their students by following these applicable recommendations in the postpandemic period:

- Conduct more training sessions for students on how to make excellent use of the Blackboard facilities.

- Conduct more training sessions for course instructors on how to make full use of the Blackboard features and icons, focusing on increasing e-learners' engagement, motivation, interaction, and achievement of the learning outcomes.

- Double the efforts to develop the university infrastructure and tackle the expected technical challenges that e-learners might encounter during their study by providing a high-speed internet connection and expanding internet coverage, particularly in small cities and geographically scattered areas.

- As the Saudi MoE declared that e-learning would be mandatory and a strategic choice in the post-pandemic period, the course contents should be redesigned to be compatible with the nature of the e-learning process. The e-learning culture should also be enhanced among students and the whole community through the various media channels.

- Establish expanded partnerships with higher education institutions that have cumulative experience in the field of e-learning.

- Students' academic and administrative services should continue to be provided electronically.

\section{References}

Abbasi, S., Ayoob, T., Malik, A., \& Memon, S. I. (2020). Perceptions of students regarding E-learning during Covid-19 at a private medical college. Pakistan Journal of Medical Sciences, 36 (COVID19-S4), 2-6. https://doi.org/10.12669/pjms.36. covid19-s4.2766

Afifi, M. K., \& Alamri, S. S. (2014). Effective principles in designing e-course in light of learning theories. Turkish Online Journal of Distance Education, 15(1), 128-142. https://doi.org/10.17718/ tojde.43806

Agarwal, S., \& Kaushik, J. S. (2020). Student's perception of online learning during Covid pandemic. Indian Journal of Pediatrics, 87(7), 554. https://doi.org/10.1007/s12098-020-03327-7

Aji, W. K., Ardin, H., \& Arifin, M. A. (2020). Blended learning during pandemic Coronavirus: Teachers' and students' perceptions. Journal of English Language Teaching and Learning: Linguistics \& Literature, 8(2). http://dx.doi.org/10.24256/ideas. v8i2.1696

Akuratiya, D., A., \& Meddage, D. N. R. (2020). Students' perception of online learning during Covid-19 pandemic: A survey study of IT students. International Journal of Research and Innovation in Social Science. 6(11), 755-758. www.rsisinternational.org 
Alahmari, A., \& Amirault, R. J. (2017). The use of E learning in highly domain-specific settings: Perceptions of female students and faculty in Saudi Arabia. The Quarterly Review of Distance Education, 18(4), 37-56

Al-Ajlan, A. (2016). A comparative study of E-learning systems in Saudi Arabia Universities. International Journal of Computer Science and Information Security, 14(12), 150-155. https://sites. google.com/site/ijcsis/ ISSN 1947-5500

Al-Asmari, A., \& Khan, S. (2014). E-learning in Saudi Arabia: Past, present and future. Near and Middle Eastern Journal of Research in Education, 2(1), 2-11. http://dx.doi.org/10.5339/ nmejre.2014.2

Aldiab, A., Chowdhury, H., Kootsookos, A., Alam, F., \& Allhibi, H. (2019). Utilization of Learning Management Systems (LMSs) in higher education system: A case review for Saudi Arabia. Energy Procedia, 160, 731-737. https://doi.org/10.1016/j. egypro.2019.02.186

Al-Fahad, F. N. (2010). The learners' satisfaction toward online e-learning implemented in the college of applied studies and community service, King Saud University, Saudi Arabia: Can E-learning replace the conventional system of education? Turkish Online Journal of Distance Education, 11(2), 61-72. https://doi.org/10.17718/tojde.13198

Al Gamdi, M. A. \& Samarji, A. (2016). Perceived barriers towards e-learning by faculty members at a Recently Established University in Saudi Arabia. International Journal of Information \& Education Technology, 6(1), 23-28. https://doi.org/10.7763/ IJIET.2016.V6.652

Al Ghamdi, A. (2017). Influence of lecturer immediacy on students' learning outcomes: Evidence from a distance education program at a university in Saudi Arabia. International Journal of Information and Education Technology, 7(1), 35-39. https:// doi:10.18178/ijiet.2017.7.1.838

Alhabeeb, A. (2018). Factors affecting the success of e-learning processes in Saudi Arabia (13873592). Available from ProQuest Dissertations \& Theses Global. (2204780373). Retrieved from https://search.proquest.com/docview/2204780373?accoun $\underline{\mathrm{tid}=142908}$

Aljaber, A. (2018). E-learning policy in Saudi Arabia: Challenges and successes. Research in Comparative and International Education, 13(1), 176-194. https://doi.org/10.1177/1745499918764147

Al-Jarf, R. (2020). Distance learning and undergraduate Saudi students' agency during the Covid-19 pandemic. Bulletin of the Transilvania University of Brasov, 13(62), 37-54. Doi:10.31926/ but.pcs.2020.62.13.2.4

Al-Juda, M. Q. B. (2017). Distance learning students' evaluation of E-learning system in University of Tabuk, Saudi Arabia. Journal of Education and Learning, 6(4), 324-335. https://doi. org/10.5539/jel.v6n4p324

Aljuhney, Y. \& Murray, L. (2016). A comparison of the utilization of E-learning Management Systems in the Republic of Ireland and Kingdom of Saudi Arabia: A case study (2015). International Journal on Recent and Innovation Trends in Computing and Communication (IJRITCC), 4(2), 1-12. http://www.ijritcc.org/

Alkhalaf, S., Nguyen, J., Nguyen, A., \& Drew, S. (2013). Online learner satisfaction and collaborative learning: Evidence from Saudi Arabia. International Journal of Information and Communication Technology Education, 9(2), 66-78. http: doi: $\underline{10.4018 / \text { iicte.2013040106 }}$
Allo, M. D. G. (2020). Is the online learning good in the midst of Covid-19 Pandemic? The case of EFL learners. Jurnal Sinestesia, 10(1), 1-10. https://sinestesia.pustaka.my.id/journal/article/ view/24

Almekhlafy, S. S. A. (2020). Online learning of English language courses via Blackboard at Saudi universities in the era of Covid-19: Perception and use. PSU Research Review, Emerald Publishing Limited, 5(1), 16-32. Doi https://10.1108/PRR-082020-0026

Almelhi, A. M. (2021). The role of the Blackboard LMS in EFL course delivery during the Covid-19 pandemic: Investigating attitudes and perceptions of faculty and students. International Journal of English Linguistics, 11(2), 46-67. https://doi:10.5539/ijel. v11n2p46

Almusharraf, N. M., \& Khahro, S. H. (2020). Students satisfaction with online learning experiences during the Covid-19 pandemic. International Journal of Emerging Technologies in Learning, 15(21), 246-267. https://doi.org/10.3991/ijet. v15i21.15647

Al-Nofaie, H. (2020). Saudi university students' perceptions towards virtual education during Covid-19 pandemic: A case study of language learning via Blackboard. Arab World English Journal, 11 (3) 4-20. Doi: https://dx.doi.org/10.24093/awej/vol11no3.1

Alowedi, N. A. (2020). Saudi Electronic University a role model in implementing blended learning: Exploring the experience of female students in the Department of English Language and Translation. International Journal of English Language Education, 8(1), 113-130. https://doi.org/10.5296/ijele. v8i1.16685

Al-Shehri, A. M. (2010). E-learning in Saudi Arabia: 'To E or not to E, that is the question'. Journal of Family and Community Medicine, 17(3), 147-150. https://dx.doi.org/10.4103\%2F1319-1683.74333

Althobaiti, M., \& Mayhew, P., (2015). Assessing the usability of Learning Management System: User Experience Study. A conference paper, Springer International Publishing, 9-18. https://dx.doi10.1007/978-3-319-28883-3 2

Aristovnik, A., Kerži `c, D., Ravšelj, D., Tomaževi `c, N., \& Umek, L. (2020). Impacts of the Covid-19 pandemic on life of higher education students: A global perspective. Sustainability, 12, 1-34. https://dx.doi:10.3390/su12208438

Asiri, M. J., Mahmud, R., Bakar, K. A., \& Ayub, A. F. (2012). Factors influencing the use of learning management system in Saudi Arabian higher education: A theoretical framework. Higher Education Studies, 2(2), 125-137. http://dx.doi.org/10.5539/ hes.v2n2p125

Bates, A. W. T. (2019). Teaching in a digital age: Guidelines for designing teaching and learning ( $2^{\text {nd }}$ ed.). Vancouver: Tony Bates Associates. https://pressbooks.bccampus.ca/ teachinginadigitalagev2/

Bolliger, D. U., \& Erichsen, E. A. (2013). Student satisfaction with blended and online courses based on personality type. Canadian Journal of Learning and Technology, 39(1), 1-24. Doi: 10.21432/T2B88W

Carr-Chellman, A., \& Duchastel, P. (2000). The ideal online course. British journal of educational technology, 31(3), 229241. https://doi.org/10.1111/1467-8535.00154

Choudhury, S., \& Pattnaik, S. (2020). Emerging themes in e-learning: A review from the stakeholders' perspective. Computers \& Education, 144, https://doi.org/10.1016/j.compedu.2019.103657区 
Choy S., McNickle, C., \& Clayton, B. (2002). Learner expectations and experiences: An examination of student views of support in online learning. Leabrook, SA: Australian National Training Authority.

Dahmash, N. (2020). 'I Couldn't Join the Session': Benefits and challenges of blended learning amid Covid-19 from EFL students. International Journal of English Linguistics, 10(5), 221-230. https://doi.org/10.5539/ijel.v10n5p221

Dziuban, C., Moskal, P., Thompson, J., Kramer, L., DeCantis, G., \& Hermsdorfer, A. (2015). Student satisfaction with online learning: Is it a psychological contract? Journal of Asynchronous Learning Network, 19(2), 1-15. https://doi.org/10.24059/olj. v19i2.496

Elzainy, A., El Sadik, A., \& Al Abdulmonem, W. (2020). Experience of e-learning and online assessment during the Covid-19 pandemic at the College of Medicine, Qassim University. Journal of Taibah University Medical Sciences, 15(6), 456-462. https://doi.org/10.1016/j.jtumed.2020.09.005

Farrah, M. \& Al-Bakry, G. H. (2020). Online learning for EFL students in Palestinian universities during Corona pandemic: Advantages, challenges and solutions. Indonesian Journal of Learning and Instruction, 3(2), 65-78. Doi: https://doi. org/10.25134/ijli.v3i2.3677

Hara, N., \& Kling, R. (1999). Students' frustrations with a web-based distance education course. First Monday, 4(12). http://dx.doi $\underline{10.5210 / \mathrm{fm} . v 4 \mathrm{i} 12.710}$

Kaur, N., Dwivedi, D., Arora, J., \& Gandhi, A. (2020). Study of the effectiveness of e-learning to conventional teaching in medical undergraduates amid Covid-19 pandemic. National Journal of Physiology, Pharmacy and Pharmacology, 10(7), 563-567. https://doi.org/10.5455/njppp.2020.10.04096202028042020

Krejcie, R. V., \& Morgan, D. W. (1970). Determining sample size for research activities. Educational and Psychological Measurement, 30, 607-610 https://doi.org/10.1177\%2F001316447003000308

Lee, L. (2016). Autonomous learning through task- based instruction in fully online language courses. Language Learning of Technology, 20(2), 81-97. http://llt.msu.edu/issues/june2016/ lee.pdf

Lee, W. J. (2010). Online support service quality, online learning acceptance, and student satisfaction. Internet and Higher Education, 13, 227-283. https://doi.org/10.1016/j. iheduc.2010.08.002

Levy, Y. (2003). A study of learners perceived value and satisfaction for implied effectiveness of online learning systems. Florida International University. ProQuest Dissertations Publishing. 3126765 .

Mahyoob, M. (2020). Challenges of e-learning during the Covid-19 pandemic experienced by EFL Learners. Arab World English
Journal, 11(4) 351-362. https://dx.doi.org/10.24093/awej/ voll1no4.23

Malkawi, E., Bawaneh, A. K., \& Bawa'aneh, M.S. (2021). Campus off, education on: UAEU student satisfaction and attitudes towards e-learning and virtual classes during Covid-19 pandemic. Contemporary Educational Technology, 13(1), 1-14. https://doi. org/10.30935/cedtech/8708

Means, B., Toyama, Y., Murphy, R., Bakia, M., \& Jones, K. (2010). Evaluation of evidence-based practices in online learning: A meta-analysis and review of online learning studies. Washington: US Department of Education.

Naveed, Q. N., Muhammed, A., Sanober, S., Qureshi, M. R. N., \& Shah, A. (2017). Barriers effecting successful implementation of E-learning in Saudi Arabian Universities. International Journal of Emerging Technologies in Learning, 12(6), 94-107. https://doi. org/10.3991/ijet.v12i06.7003

Sandybayev, A. (2020). The impact of e-learning technologies on students' motivation: Student-centered interaction in business education. International Journal of Research in Tourism and Hospitality, 6(1), 16-24. http://dx.doi.org/10.20431/2455$\underline{0043.0601002}$

Shea, P. J., Pickett, A. M., \& Pelz, W. E. (2003). A follow-up investigation of teaching presence in the SUNY learning network. Journal of Asynchronous Learning Networks, 7(2), 61-80. DOI: 10.24059/olj.v7i2.1856

Stefanovic, D., Drapsin, M., Nikolic, J., Scepanovic, D., Radjo, I., \& Drid, P. (2011). Empirical study of student satisfaction in e-learning system environment. Technics Technologies Education Management, 6(4), 1152-1164.

Sujarwo, S., Sukmawati, S., Akhiruddin, A., Ridwan, R., \& Siradjuddin, S. (2020). An analysis of university students' perspective on online learning in the midst of Covid-19 pandemic. Jurnal Pendidikan dan Pengajaran, 53(2), 125-137. https://doi.org/10.23887/jpp.v53i2.24964

Taylor, P. S. (2007). Can clickers cure crowded classes? Maclean's, $120,26-27,73$.

Temizer, L., \& Turkyilmaz, A. (2012). Implementation of student satisfaction index model in higher education institutions. Procedia - Social and Behavioral Sciences, 46, 3802-3806. https://doi.org/10.1016/j.sbspro.2012.06.150

Vonderwell, S., \& Turner, S. (2005). Active learning and preservice teachers' experiences in an online course: A case study. Journal of Technology and Teacher Education, 13(1), 65-85.

Xiong, W., Mok, K. H., \& Jiang, J. (2020). Hong Kong University students' online learning experiences under the Covid-19 pandemic. https://www.hepi.ac.uk/2020/08/03/hong-konguniversity-students-online-learning-experiences-under-thecovid-19-pandemic/ 